\title{
Caddo Ceramic Vessels from the Mrs. Martin Farm, Harrison County, Texas
}

Timothy K. Perttula

Heritage Research Center, Stephen F. Austin State University

Bo Nelson

Heritage Research Center, Stephen F. Austin State University

Follow this and additional works at: https://scholarworks.sfasu.edu/ita

Part of the American Material Culture Commons, Archaeological Anthropology Commons, Environmental Studies Commons, Other American Studies Commons, Other Arts and Humanities Commons, Other History of Art, Architecture, and Archaeology Commons, and the United States History Commons

Tell us how this article helped you.

This Article is brought to you for free and open access by the Center for Regional Heritage Research at SFA ScholarWorks. It has been accepted for inclusion in Index of Texas Archaeology: Open Access Gray Literature from the Lone Star State by an authorized editor of SFA ScholarWorks. For more information, please contact cdsscholarworks@sfasu.edu. 


\section{Caddo Ceramic Vessels from the Mrs. Martin Farm, Harrison County, Texas \\ Creative Commons License \\ (c) (1) \& 8}

This work is licensed under a Creative Commons Attribution-NonCommercial 4.0 International License 


\section{Caddo Ceramic Vessels from the Mrs. Martin Farm, Harrison County, Texas}

Timothy K. Perttula and Bo Nelson

\section{INTRODUCTION}

The Mrs. Martin Farm site is a Caddo site in the community of Darco, in south central Harrison County, in the Sabine River basin of the East Texas Pineywoods. The farm was investigated by C. W. Bailey in March 1941, and two Caddo ceramic vessels recovered in this work at depths of ca. 36 and $76 \mathrm{~cm}$ bs are now curated at the Gregg County Historical Museum. These vessels are likely funerary offerings from two different burials at the site.

\section{VESSELS}

SITE NAME OR SITE NUMBER: Mrs. Martin Farm, $76 \mathrm{~cm}$ bs

VESSEL NO.: 2003.08.342

NON-PLASTICS AND PASTE: grog

VESSEL FORM: Bowl

RIM AND LIP FORM: Inverted rim and rounded lip

CORE COLOR: B (fired and cooled in a reducing environment)

INTERIOR SURFACE COLOR: very dark grayish-brown

EXTERIOR SURFACE COLOR: dark grayish-brown

WALL THICKNESS (RIM, BODY, AND BASE IN MM): rim, 7.4 mm

INTERIOR SURFACE TREATMENT: none

EXTERIOR SURFACE TREATMENT: smoothed

HEIGHT (IN CM): 5.4

ORIFICE DIAMETER (IN CM): 10.1

DIAMETER AT BOTTOM OF RIM OR NECK (IN CM): N/A

BASE DIAMETER (IN CM) AND SHAPE OF BASE: 7.5; circular and flat

ESTIMATED VOLUME (IN LITERS): 0.22 
DECORATION (INCLUDING MOTIF AND ELEMENTS WHEN APPARENT): Plain (Figure 1)

PIGMENT USE AND LOCATION ON VESSEL: none

TYPE AND VARIETY [IF KNOWN]: Unidentified plain ware
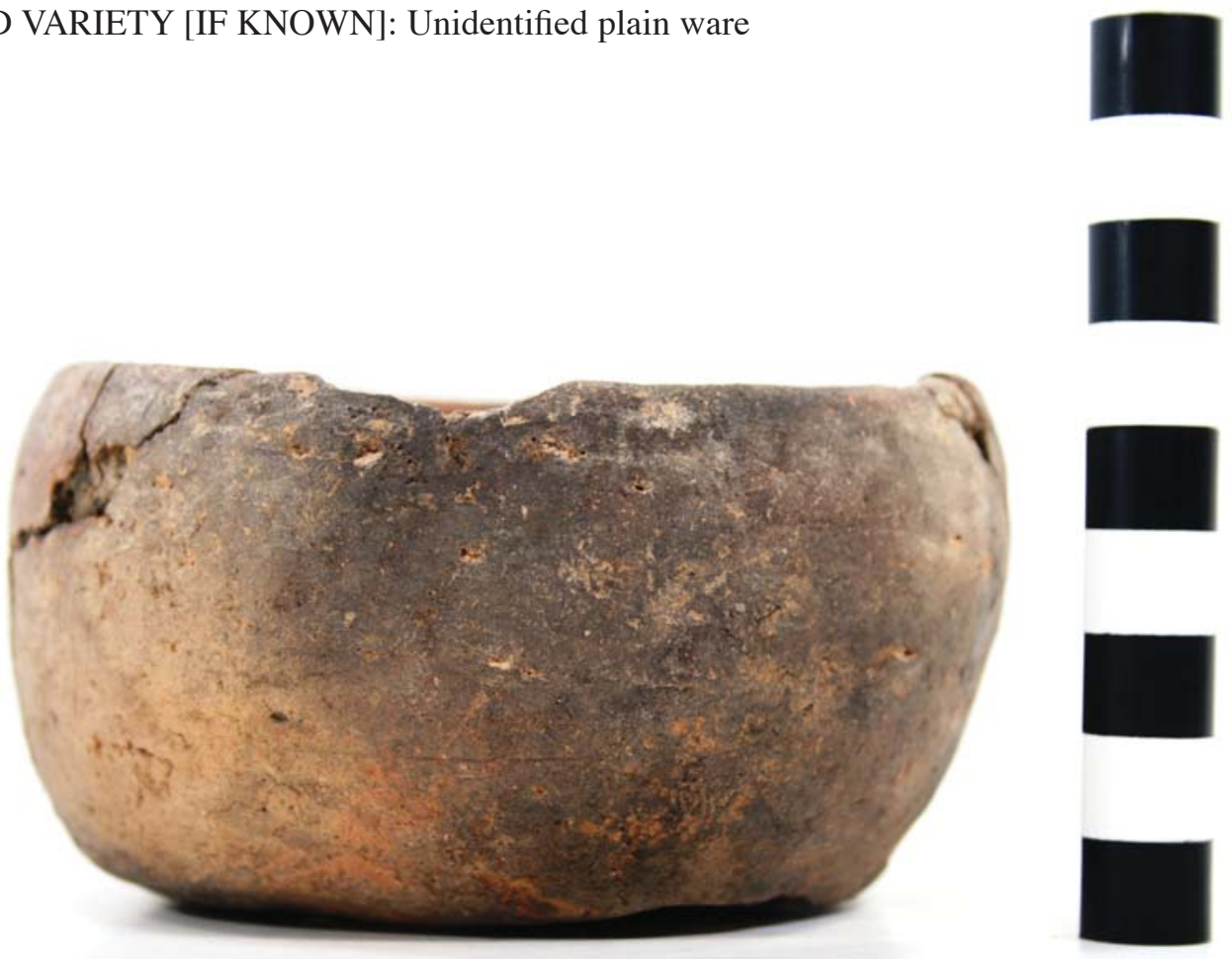

Figure 1. Plain bowl, Mrs. Martin Farm site.

SITE NAME OR SITE NUMBER: Mrs. Martin Farm, $36 \mathrm{~cm}$ deep

VESSEL NO.: 2003.08.344

NON-PLASTICS AND PASTE: grog

VESSEL FORM: Jar

RIM AND LIP FORM: Everted rim and rounded lip

CORE COLOR: $\mathrm{F}$ (fired in a reducing environment and cooled in the open air)

INTERIOR SURFACE COLOR: reddish-brown; fire cloud on the base

EXTERIOR SURFACE COLOR: dark yellowish-brown; fire clouds on the rim, body, and base

WALL THICKNESS (RIM, BODY, AND BASE IN MM): rim, 6.6 mm

INTERIOR SURFACE TREATMENT: smoothed

EXTERIOR SURFACE TREATMENT: burnished 
HEIGHT (IN CM): 6.4

ORIFICE DIAMETER (IN CM): 9.1

DIAMETER AT BOTTOM OF RIM OR NECK (IN CM): 8.2

BASE DIAMETER (IN CM) AND SHAPE OF BASE: 5.5; circular and rounded

ESTIMATED VOLUME (IN LITERS): 0.35

DECORATION (INCLUDING MOTIF AND ELEMENTS WHEN APPARENT): The rim has an engraved scroll motif repeated four times around the vessel. The central element in the scroll motif is a large hatched circle; in two cases, there is a single curvilinear engraved line near the hatched circles. The scroll line has excised pendant triangles that face towards the vessel base, and there are scattered excised triangles on a horizontal engraved line at the rim-body juncture (Figure 2a-b); these point towards the vessel rim.

PIGMENT USE AND LOCATION ON VESSEL: none

TYPE AND VARIETY [IF KNOWN]: Unidentified fine ware
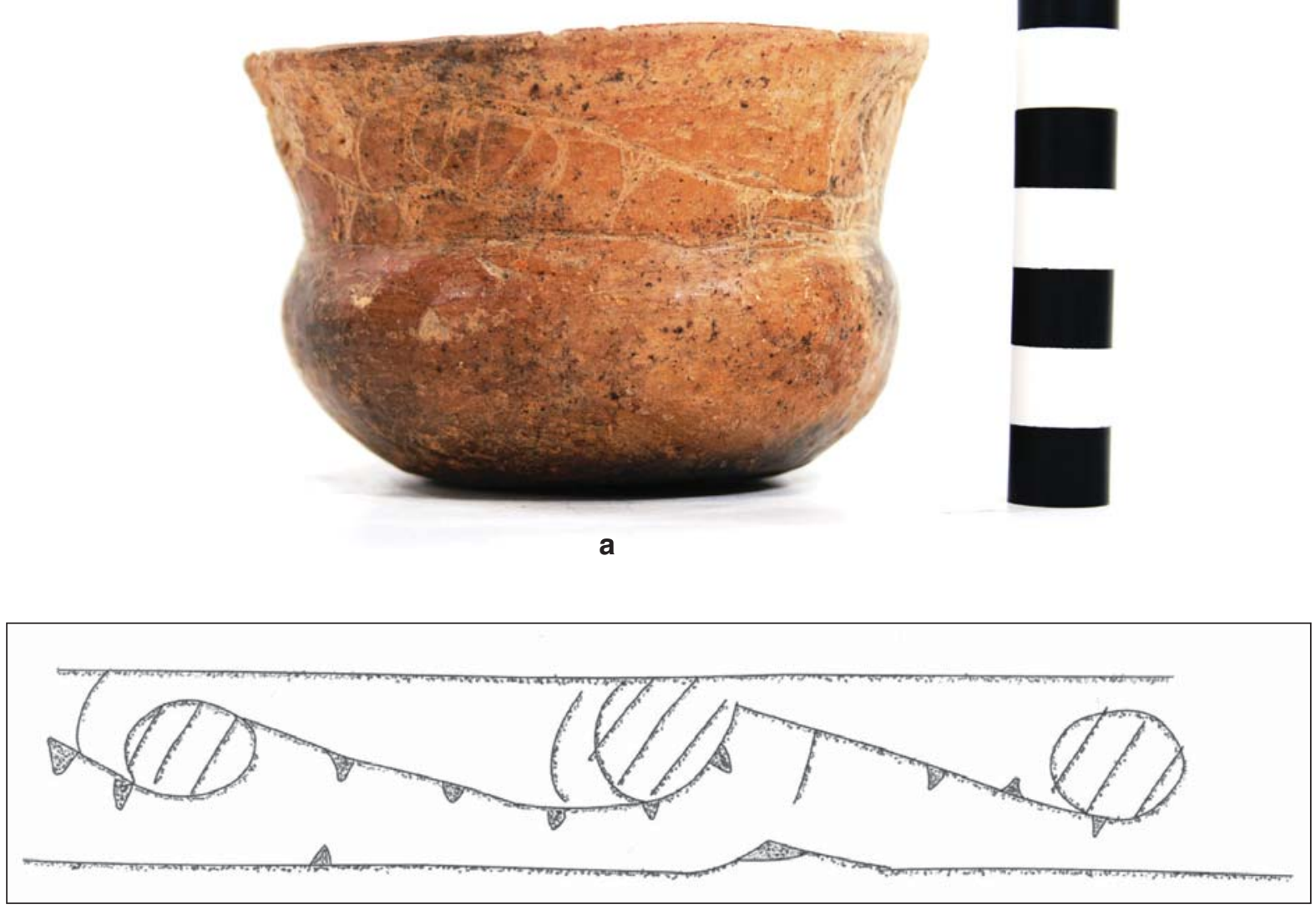

b

Figure 2. Engraved jar, Mrs. Martin Farm site: a, photograph; b, motif drawing. 


\section{SUMMARY AND CONCLUSIONS}

Two small grog-tempered Caddo ceramic vessels were excavated by C.W. Bailey in 1941 from the Mrs. Martin Farm in the community of Darco in south central Harrison County, Texas. The vessels are now in the Gregg County Historical Museum collections. The depths of the two vessels suggest they were funerary offerings in two different burials at the site, perhaps burials of children given their small size, although the contexts of the vessels are not known.

The scroll and hatched circle engraved motif on one vessel-although a jar-resembles the scroll and circle motif seen on Late Caddo Titus phase Ripley Engraved vessels in both the Sabine River and Big Cypress Creek basins. On that basis, it is suggested that the Mrs. Martin Farm site has a post-A.D. 1450 Caddo cemetery on it.

\section{Acknowledgments}

We thank Patti Haskins of the Gregg County Historical Museum for facilitating this documentation work. 